\title{
On Death and Loss in Queer and Trans lives
}

\author{
Varpu Alasuutari
}

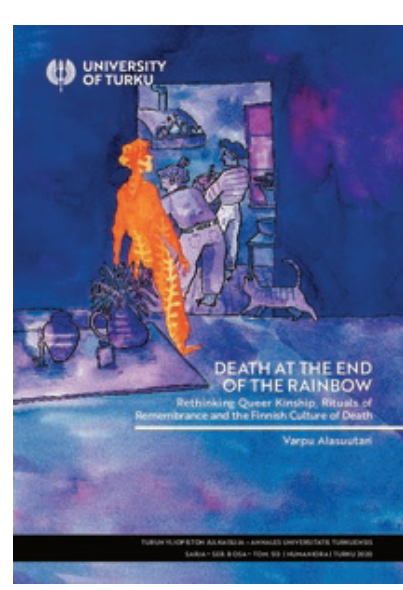

Varpu Alasuutari's Ph.D. dissertation Death at the End of the Rainbow: Rethinking Queer Kinship, Rituals of Remembrance and the Finnish Culture of Death was publicly examined on 5 June 2020 at the department of Gender Studies, University of Turku. Opponent was doctor Riikka Taavetti, University of Helsinki, and Custodian was professor Marianne Liljeström, University of Turku.

Alasuutaris dissertation is available in electronic form through UTUPub service:

https://www.utupub.fi/handle/10024/149503
We are here today to talk about death. ${ }^{1}$ As grim as it sounds, life and death are closely linked to each other. As death is always part of life - both in the form of people's own, eventual deaths and the deaths of others - it is also part of queer and trans lives.

In my dissertation, titled Death at the End of the Rainbow: Rethinking Queer Kinship, Rituals of Remembrance and the Finnish Culture of Death, I have studied death and loss among LGBTQ people living in Finland. The alphabet, here, refers to lesbians, gays, bisexuals, transgender people and queers, describing how the participants of the study self-identified.

I have approached my topic by interviewing and collecting written narratives from 14 bereaved LGBTQ people living in Finland. Their rich and detailed stories describe a variety of losses, including deaths of partners, ex-partners, parents, grandparents, friends and other people who the interviewees found meaningful in their lives in one way or another. In addition, following the principles of scavenger methodology, as described by Jack Halberstam (1998), I have collected complementary data in order to contextualise the personal stories of loss with Finnish society in which

1 In Finland a doctoral thesis defence is a public event, in the beginning of which the doctoral candidate gives a 20 minute talk about their thesis, called lectio praecursoria.
SQS

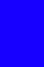

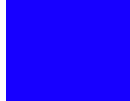

(1) 
they have occurred. This complementary data includes legislative texts, church guidelines, online ethnography, and an expert interview.

\section{Challenging compulsory happiness}

In choosing this topic, I have been following the research tradition emerging around negative affects in queer studies. This tradition calls for research that sees through the compulsory happiness of queer existence (Love 2007), and while doing so, does not overlook the negative or painful aspects of the lives that are lived outside, or in the margins of, the heteronormative and cisnormative ways of living.

It can be said that in conducting this study, I have, in the words of Donna Haraway (2016), 'stayed with the trouble'. Death certainly is something that troubles us as human beings. Although death often appears as a taboo and as something not easily discussed, the current times of the COVID-19 pandemic have reminded us all of the inherent vulnerability of our lives and the lives of others. With or without a global pandemic, however, death is always waiting behind the corner. Thus, death is hardly a marginal topic when studying any kinds of human lives.

\section{Queering death studies}

When I was sketching the early research proposal for this study in 2014, the interdisciplinary research field called queer death studies did not yet exist. Today, such a field is emerging through the joint efforts and collaboration of an international group of scholars in the Queer Death Studies Network, interested in queering the field of death studies in different ways (Radomska et al. 2019).
Besides gender studies and queer studies, I consider queer death studies as one of the fields I am contributing to with this dissertation. My contribution in this regard is both empirical and theoretical, in the sense of "searching points of exit from hegemonic narratives" describing death and loss, which often have focused on normative understandings of losses that matter (QDSN 2020).

My theoretical framework is interdisciplinary, drawing mainly on feminist affect theories, queer theory, death studies, and bereavement studies, but also on trans studies, social sciences, anthropology, and religious studies. I have found such a wide array of theories not only useful but also necessary in analysing and understanding the versatile and entangled issues discussed in my dissertation. Methodologically, I have followed feminist methodologies when discussing how the vulnerable stories of not-onlyvulnerable others can be told in ethical ways and aiming to be a vulnerable observer, writing vulnerably, and self-reflexively, about my observations.

\section{Hidden inequalities of death}

Temporally, the events shared with me by the interviewees took place between the 1980s and the late 2010s. This was not a planned temporal frame, but rather, a result from reaching interviewees who happened to tell their stories from this era. However, this is also a rich and interesting era because of the legislative and attitudinal changes that have taken place in Finland during those same decades. For example, homosexuality was depathologised in 1981, the laws on gender reassignment and registered partnership of same-sex couples took effect in the early 2000s, and, eventually, the law on same-sex marriage took effect in 2017. This is not to say, however, that equality would have been achieved in Finland by these changes within this time period, despite the popular progress narrative celebrating Finland as the role model country of equality.
SQS

$1-2 / 2020$

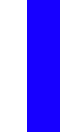


In my dissertation I go against the grain of this narrative and pay attention to the hidden inequalities prevailing in the Finnish culture of death. Some of them are structural or cultural, resulting from legislation or cultural habits. In addition, as I show in the study, inequalities may also operate on the level of affects. This means that they appear on the level of intensities, sensations, and emotions that may be difficult to verbalise or pin down, experienced in relation to their structural and cultural surroundings. Such inequalities may surface in relation to questions such as: what counts as a meaningful loss or a relationship, what counts as a family or the next of kin in the context of death, what are the proper ways to bid farewell to and to remember the lost other, who can we turn to for support when losing people we care about, and how, and by whom, do we want to be remembered when we die. These are questions that I address in the empirical chapters of the dissertation.

\section{The changing scope of research}

Conducting this study has been a lively process. In other words, it has changed and evolved along the way, and its scope has not always been so wide. Instead, I started it as a study of LGBTQ people and partner-loss in Finland, inspired by other studies conducted abroad with similar topics. At the time of planning the study, same-sex marriage was in the process of being legalised in Finland, but the law had not yet come into effect. Although the law on registered partnership already existed, same-sex couples often found a separate law demeaning and, as a result, did not always consider it as a viable or fair option for making their partnership official. In this societal context, I suspected that partner-loss among LGBTQ people could have distinctive features worthy of studying.

In the process of researching, however, I realised that there is much more to be said about death and loss in queer and trans lives. Focusing only on the loss of romantic relationships through death would leave out a variety of relationships that are, in different ways, significant in the lives of LGBTQ people. In order to avoid amatonormativity - that is, an unjustified privilege and overemphasis of romantic relationships (Brake 2012) - it was thus reasonable to widen the scope of the research to include other kinds of losses as well. Through this decision, it became possible to discuss not only partner-loss, but also losses of friends and ex-partners, for example. Moreover, the change of scale made it also possible to discuss the affective specificities of losing parents and grandparents. As I found out, these were quite different experiences depending on how the lost family member had dealt with sexual and gender minorities. For example, if the relationship with a parent had been a complicated or disrespectful one, this affected also the loss of, and the grieving for, such a parent.

\section{Queer kinship in the case of death}

Meaningful relationships in varying forms, theorised as queer kinship, ended up becoming one of the key themes of this study. In my process of analysing and making sense of the stories told, I relied on feminist affect theories with a focus on families, happiness and the good life, especially by Sara Ahmed (2010) and Lauren Berlant (2011). I argued that the normative ideals of what counts as families in the fantasies of the good life affect also what counts as families, or meaningful relationships, in the context of the good death. The normative family ideals prevail and manifest, for example, in the family grave tradition supported by Finnish legislation and in the funeral etiquette supported by guidelines given by the Evangelical Lutheran Church, the biggest religious institution in Finland. The established traditions hierarchise and differentiate between family members and other mourners. In these contexts, what counts as family is defined by law and shared bloodlines.
SQS

$1-2 / 2020$ 
For people leading queer and trans lives, however, this normative matrix may not be sufficient when considering the myriad of meaningful relationships. While people in general, and LGBTQ people in particular, may live their lives according to more diverse family ideals, the normative ideal catches us up in the context of death, suggesting that a difference needs to be made between those family members who are official in the eyes of the state and those who are not. The former includes parents, siblings, biological or adopted children, and registered or married partners. The latter, in turn, includes friends, unofficial partners, multiple partners, ex-partners, and other meaningful relationships that are not legally recognised as familial. This differentiation comes up, for example, when deciding who are treated as the primary mourners of the deceased, who can organise the funeral, who can be buried together, who can inherit the deceased, or how people are expected to grieve the loss. However, the official or unofficial family status does not always predict or define the depth of the relationship, the intensity of grieving, or the ways people want to participate in the rituals and processes following the loss.

In queer kinship studies, a differentiation is often made between the biological and the chosen kin. My focus on the official and the unofficial kin aims at complicating this differentiation, focusing not on choice or biology but on what is legally recognised. However, legal recognition does not always lead to social recognition; and sometimes relationships not legally recognised may be socially recognised, which further complicates this division. Moreover, as I propose, kinship is not something that only appears among the living. The lost meaningful others kept having importance in the lives of the interviewees, suggesting that the feeling of kinship does not necessarily end in death. Therefore, I suggest that kinship is complex, breaking the binaries of the biological and the chosen kin, the official and the unofficial kin, as well as the living and the dead. Given this multilayered nature of kinship within the stories of bereavement, I argue that my dissertation ended up becoming a study of the complex relationships of LGBTQ people, of the complicated affects that were ingrained in those relationships, and of what happened to kinship when death cut some of those relationships apart.

\section{Complex losses and rituals}

Over the course of conducting this study, as I encountered increasingly complicated and multi-layered relations, I ended up problematising, or rethinking, the concepts and theories I was drawing on. For instance, I noticed that the theories I initially followed, including sociologist Kenneth Doka's (2002) theory of disenfranchised grief and queer theorist Judith Butler's $(2004 ; 2009)$ theory of ungrievability, return, first and foremost, to questions of inclusion and exclusion. These theories ask who can be grieved and recognised as lost; and who can be recognised as people grieving the loss. However, as my study shows, these are not simple, black-and-white questions. With an analytical focus on norms and affects attached to them, or affective normativities as I call them, I have shown that often it is a question of feeling included or feeling excluded, manifesting in different ways in different contexts. Thus, instead of being entirely disenfranchised or ungrievable, I argue that the lives and losses of LGBTQ people in Finland can more often be seen as both disenfranchised and enfranchised, both ungrievable and grievable at the same time, depending on the context.

Rituals, too, appeared as complex. In this study I have made an analytical differentiation between rituals of death and rituals of remembrance. The former refers to rituals aiming to bid farewell to the lost person, often in culturally prescribed and established ways, like funerals. The latter, in turn, refers to rituals created by the interviewees themselves, often less strongly culturally prescribed, performed either in private or with their
SQS

$1-2 / 2020$ . 
private networks. Instead of bidding farewell, these rituals were about keeping the memory of the lost one alive. These included, for instance, creating commemorative events, talking to the lost other, holding on to keepsakes as memory objects, and visiting the grave or other places with similar affective significance. With the inspiration of queer theory and bereavement studies, I have theorised the rituals of remembrance as examples of melancholic attachments, or continuing bonds, which can be beneficial in the midst of grief and, in the words of José Esteban Muñoz (1999), help to 'take our dead with us to the various battles we must wage in their names - and in our names'.

\section{Culture(s) of death in Finland}

The final question I wish to address is: what can we say about the Finnish culture of death based on this study? I argue that the Finnish culture of death heavily prioritises the official family of the deceased, as well as the Evangelical Lutheran Church as an institution. The official family of the lost are those heightened as the primary mourners with both rights and responsibilities in the context of loss, granted by legislation and cultural habits. The Church institution, in turn, has power to influence and maintain these cultural habits in defining death rituals and maintaining the vast majority of Finnish cemeteries, guiding also how lost people can be honoured in gravesite memorials. Given the tense relationship between LGBTQ people and the Church institution in Finland, resulting from the inability of the Church to treat LGBTQ people with "fully equal respect” (Hellqvist \& Vähäkangas 2018), I argue that having to face this prioritised role of the Church can be challenging for bereaved LGBTQ people, regardless of their personal worldviews.

However, I do not claim that the Finnish culture of death is a monolith with no variation nor a possibility to change and be altered. Instead,
I suggest that there are, and could be, cultures of death in Finland, in which also the needs and specificities of LGBTQ people are taken into consideration. Such culture is important also in terms of cultural memory and in deciding which lives get remembered in public. In my dissertation I argue that the public rituals of remembrance performed by Finnish LGBTQ communities, including, for instance, the Transgender Day of Remembrance, can be seen as examples of queer and trans culture of death in Finland. At the moment, such culture seems to focus more on public, political and internationally circulated queer and trans deaths and losses than on private and unpolitical ones.

On this note, I propose that we need also other types of queer and trans culture of death: culture that would focus on death and loss as inseparable parts of all queer and trans personal lives. It could include, for example, taking different family forms into consideration in the case of death, offering information and examples of death rituals that go beyond the culturally established and hierarchical ones, making queer and trans lives visible in the Finnish cemeteries through techniques of queer monumentality, and creating queer- and trans-sensitive bereavement support services. Because all of us are eventually dying and losing our meaningful others to death, having varied cultural examples to follow, having accessible support services, and having communities to back us up when that happens would, as I suggest, help LGBTQ people to live through the emotionally demanding times of bereavement.

This study has evolved, broadened and crystallised when necessary, and as a result, ended up answering to much larger questions than what I initially had in mind. As it stands, it is a study that brings new insight into the experiences of death and loss in queer and trans lives in Finland. This insight is applicable also in terms of other lives that are in different ways casted in the margins within the Finnish culture of death. Moreover,
SQS

$1-2 / 2020$ 
the study produces new knowledge on the conditions of living queer and trans lives in Finnish society, particularly in terms of kinship, rituals and

\section{Bibliography}

Ahmed, Sara. 2010. The Promise of Happiness. Durham: Duke University Press.

Alasuutari, Varpu. 2020. Death at the End of the Rainbow: Rethinking Queer Kinship, Rituals of Remembrance and the Finnish Culture of Death. Annales Universitatis Turkuensis. Ser B:513. Humaniora. Turku: University of Turku. <https://www.utupub.fi/handle/10024/149503>

Berlant, Lauren. 2011. Cruel Optimism. Durham: Duke University Press.

Brake, Elizabeth. 2012. Minimizing Marriage: Marriage, Morality, and the Law. New York: Oxford University Press.

Butler, Judith. 2004. Precarious Life: The Powers of Mourning and Violence. London: Verso.

Butler, Judith. 2009. Frames of War: When Is Life Grievable? London: Verso.

Doka, Kenneth J. (ed.). 2002. Disenfranchised Grief. New Directions, Challenges and Strategies for Practice. Champaign: Research Press.

Halberstam, Jack. 1998. Female Masculinity. Durham: Duke University Press.

Haraway, Donna J. 2016. Staying with the Trouble: Making Kin in the Chthulucene. North Carolina: Duke University Press.

Hellqvist, Elina \& Vähäkangas, Auli. 2018. "Experiences of (Mis)Recognition of Same-Sex Partnerships in the Evangelical Lutheran Church of Finland." Exchange 47(3): 258-281.

Love, Heather. 2007. "Compulsory Happiness and Queer Existence." New Formations 63: 52-64.

Muñoz, José Esteban. 1999. Disidentifications: Queers of Color and the Performance of Politics. Minneapolis: University of Minnesota Press.

QDSN. 2020. Queer Death Studies Network. Last accessed June 4, 2020. <https:// queerdeathstudies.net>

Radomska, Marietta; Mehrabi, Tara \& Lykke, Nina. 2019. “Queer Death Studies: Coming to Terms with Death, Dying and Mourning Differently. An Introduction.” Kvinder, Køn og Forskning 28(3-4), 3-11. 